VISNYK LVIV UNIV.

ерія геогр. 2012. ип. 40. . . 1. . 46-53 Ser. Geogr. 2012. N 40. . 1. P. 46-53

$551.4+911.2$

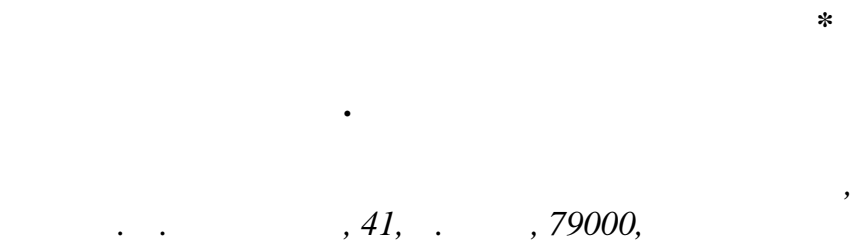

федр р ціон льного використ ння природних ресурсів і охорони природи ьвівського н ціон льного університету імені в н р нк утворен в 1988 році. того ч су викл д чі, співробітники т спір нти к федри плідно співпр цюють з н уковим вид нням - ісником ьвівського університету. ерія геогр фічн . його сторінк х вони опублікув ли м йже 150 пр ць. ст тті про н лізов но н уковий доробок співробітників к федри, зокрем ту його скл дову, що відоб$\mathrm{p}$ жен в різних випуск х існик, под но б чення співробітник ми к федри перспективних н прямків н укових досліджень.

лючові слов : к федр , існик, н укові інтереси, н укові досягнення, перспективні н прямки досліджень.

2012 році мин є 50 років з ч су виходу першого числ ф хового геогр фічного вид ння - “ існик ьвівського університету. ерія геогр фічн” (д лі - існик). вілейн д т , з звич й, спонук є $з$ дум тися н д тим, що зроблено $з$ цей період, що не вд лося зробити, зокрем, яким чином це вид ння вплив ло н ст новлення окремих особистостей к федри і яку роль вони відігр ли у ст новленні цього вторитетного вид ння.

федр p ціон льного використ ння природних ресурсів і охорони природи співпр цює 3 ісником з ч су її утворення. унд тори к федри - професор . униця, доцент . . укурудз (з 2000 р. професор), систенти, згодом доценти, к ндид ти геогр фічних н ук . . ілецький, . ойков , . . тойко, т кож ст рший л бор нт

. . иротюк (з 1997 р. к ндид т геогр фічних н ук, доцент) - опублікув ли свої перші розвідки у існику ще в середині 70-х - н поч тку 80-х років минулого століття. нші викл д чі, зокрем професор . униця - 3 відув ч к федри в 1988-2003 рр., нині ректор ціон льного лісотехнічного університету кр їни, к демік кр їни, співпр цюв в з ісником як член редколегії.

об молоді н уковці змогли кр ще предст вити яким в перші десятиліття був існик, звернемо ув гу н деякі його тодішні х р ктерні озн ки:

- вид в вся перев жно один р з у дв роки;

- форм т, як і обсяг, були зн чно меншими в порівнянні з нинішнім;

- друк був офсетним, п пір - г зетним.

им не менше, опублікув ти ст ттю у існику було не бияким успіхом, особливо для молодих учених. бсяг ст тей був обмежений трьом -чотирм сторінк ми. дже пот-

* т ття друкується в вторській ред кщії.

(C) укурудз ., 2012 
реб і б ж ння опублікув ти результ ти своїх досліджень були в усіх викл д чів ф культету, співробітників грунтозн вчої експедиції, шт т якої в н йкр щі ч си н р ховув в пон д сотню пр цівників, спір нтів, інженерів й л бор нтів. одноч с з зн чимо, що викл д цький скл д ф культету в той ч с був вчетверо меншим - (у 1978 р. - 24 пос ди, нині - пон д 100). т тус спір нт вз г лі був рідкістю - одне ст ціон рне місце виділялося р з у три-чотири роки.

ч су здобуття кр їною нез лежності випуски існик ст ли щорічними, змінився їх форм т, суттєво збільшився обсяг т поліпшився друк. окремі роки вид в лося н віть по дв випуски. того ч су є змог опер тивно, без сторонніх втруч нь, публікув ти результ ти досліджень бюджетних, к федр льних, госпдоговірних тем, дисерт ційних робіт. існик ст в для викл д чів, співробітників т спір нтів усіх к федр ф культету своєрідною “трибуною” для проб ції результ тів н укових досліджень. ост нні роки н його сторінк х висвітлюють результ ти своїх н укових розвідок спір нти й пошукув чі н укового ступеня з геогр фії не тільки н шого, й сусідніх, н с мперед ернівецького, жгородського т олинського “кл сичних" т в но- р нківського, ернопільського, рогобицького пед гогічних університетів.

икл д основного м тері лу. еред тим, як Н лізув ти співпр цю співробітників к федри з ісником, слід кільком штрих ми їх предст вити. тосовно викл д цького скл ду к федри, то н поч тку її діяльності він скл д вся із вищезг д них п’яти осіб. першому десятилітті рот ція к дрів відбув л ся досить ч сто і з 6 г тьох причин. рофесор уницю . . в 1993 р. обр но ректором ьвівського лісотехнічного університету, ле з відув чем к федри він з лиш вся до 2003 р. . ілецький, отрим вши зв ння доцент, повернувся н к федру економічної т соці льної геогр фії. . ойков виїх л в осію (чоловік - військовий, отрим в нове призн чення). им ч сом, з хистили к ндид тські дисерт ції перші спір нти т пошукув чі к федри - . иротюк, . ойнов , . едунь, . ожкко, . енчин, . inm ч, . утинський, які посіли викл д цькі пос ди і $з$ мінили 6 г тьох викл д чів, які пр цюв ли н к федрі з сумісництвом.

ч с ст новлення к федри в її скл ді викл д ч ми-сумісник ми пр цюв ли відомі вчені з великим пед гогічним і життєвим досвідом, яким вони охоче ділилися з молодшими колег ми, спір нт ми т студент ми. е, н с мперед, доктор біологічних н ук, професор . . тойко, який н ф культеті викл д в пон д чверть століття (до утворення к федри він десять років пр цюв в н к федрі фізичної геогр фії). Г льний н уковий доробок професор н р ховує пон д 600 публік цій, з них: 15 моногр фій, шість н вч льних посібників і словників, $11-$ н уково-популярних книг, сотні ст тей $з$ яких дві опубліков ні у існику. гроекологію чит в д. б. н., к демік , професор

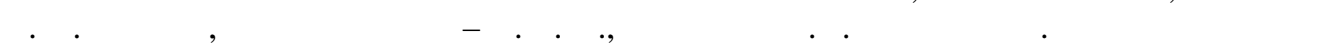
підготув ли д. ф.- м. н., професор . . ебединець; д. м. н., професор - . . ненко; д. ю. н., професор . . $\quad$ р вченко; д. б. н., с. н. с. . . ретяк т інші.

деського університету в 1989 р прибув к. г. н. (з 1996 р. - д. г. н.), доцент (з 2000 р.професор) . . олошин, який пр цюв в н к федрі до 2010 р. (тепер з відув ч к федри туризму ьвівського університету фізичної культури). ін підготув в н к федрі докторську дисерт цію, вид в n'ять моногр фій т низку н вч льних посібників, підготув в чотирьох к ндид тів н ук. існику р зом з учнями ним опубліков но 19 пр ць.

1996 р. $з$ ьвівського лісотехнічного університету перевівся к. філософ. н. (з 2010 р.д. г. н.), доцент (з 2010 р. - професор) . . 3 рук. елику ч стку н укового доробку, який н р ховує пон д сотню пр ць він т кож підготув в н к федрі. 
ким чином, якщо в 1988-1989 рр. в шт ті к федри було п’ять викл д чів, один л бор нт і один спір нт ( $і л о y c$. .), то в 2011-2012 н. р. викл д цький скл д к федри н р ховує вже 12 осіб: з них дв професори, сім доцентів, три систенти (див. вкл. 5).

к федрі без відриву від виробництв н вч ється п’ять спір нтів: . рии й, нтошик, · ольов, . епеняк, . ребтієвький т три ст ціон рно: . удоб, - льчищин, . олов тий.

чотирьох шт тних пос д х н вч льно-допоміжного персон лу к федри пр цюють п’ять осіб: $з$ відув ч л бор торії екологічної експертизи, к.г.н. . еліш, ст. л б. . рук $i$. удоб - (ділять одну ст вку) т інженери н вч льної л бор торії - . pук $i$. $u$ $\kappa$ йло. сі вони ктивно співпр цюють 3 ісником. т кі числ існик як 17, 26 і 37 підготовлені до вид ння з безпосередньою уч стю співробітників к федри.

ч с своєї діяльності к федр підготув л сотні ф хівців з вищою освітою 3 н пряму геогр фія (р ціон льне використ ння природних ресурсів і охорон природи) т менеджменту (менеджмент природоохоронної діяльності). $\quad$ к федрі підготовлено й з хищено дві докторські т 17 к ндид тських дисерт цій. е чотири - учм нич . ., урсь$\kappa$.., обечко . ., икитч $\kappa . .-$ рекомендов ні до з хисту. тлі з г льного н укового доробку стисло зупинимося н особистому доробку співробітників к федри, їхній співпр ці з ісником т перспективних н прямк х досліджень.

відув ч к федри професор укурудз .. є втором і спів втором пон д $180 \mathrm{H}$ укових пр ць, з них чотири моногр фії, один підручник т вісім посібників для вищих н вч льних $з$ кл дів, дв з яких - рекомендов ні кр їни. ершу ст ттю спільно 3 своїм н уковим керівником - професором еренчуком ... опублікув в в десятому числі існик (1976 р.). сього у існику ним опубліков но 18 пр ць.

укові інтереси укурудзи .. стосуються широкого кол пит нь, які вписуються в т кі еколого-геогр фічні н прямки:

- теорія й методик л ндш фтозн вств ;

- метриз ція, нтропіз ція т моніторинг л ндш фтних систем;

- оцінюв ння екологічної ситу ції, ст ну використ ння т охорони природних л ндш фтів, історії геогр фії тощо.

ід керівництвом професор укурудзи ... к ндид тські дисерт ції з хистили семеро спір нтів т пошукув чів ( иротюк .., 1997, ойнов . ., 1999, едунь . ., 1999, inm ч . ., 2001, утинський . ., 2002, льён . ., 2006, л жкко . ., 2010) исерт ційні роботи двох спір нтів - учм нич . . $і$ урської . .- рекомендов ні до 3 хисту.

К н уковець і викл д ч професор укурудз . . пл нує зосередитися н : $\rightarrow$ підготовці моногр фії;

$\rightarrow$ н вч льного посібник ;

$\rightarrow$ роботі з спір нт ми т пошукув ч ми.

рофесор 3 рук. . є втором т спів втором 110 н укових $n p$ ць, з яких дві моногр фії, один підручник $m$ сім посібників для вищих н вч льних 3 кл дів, 57 ст тей, з яких 18 - опубліков ні у існику.

фер н укових інтересів: проблеми вз ємодії суспільств і природи; екологічн освіт т їі філософсько-методологічні основи; філософські проблеми природозн вств ; екологічні т соці льні проблеми м. ьвов ; екологічний менеджмент. перспективі пл нує зосередитися н підготовці:

$\rightarrow$ моногр фії “ ьвів-з роки нез лежності”;

$\rightarrow$ н вч льного посібник “ оці льн екологія"; 
$\rightarrow$ роботі з спір нт ми.

оцент inm ч . . фер його н укових інтересів: метриз ція екологічних ст нів л ндш фтів, р ціон льне землекористув ння й охорон земель, екологічн депресивність регіонів, менеджмент т орг ніз ція природоохоронної діяльності.

уковий доробок: три моногр фії, один н вч льний посібник (гриф ), один біобібліогр фічний пок жчик, 31 ст ття, зокрем - 19 у ф хових вид ннях, в тому числі $11-\mathrm{y}$ існику.

л нує зосередити зусилля н :

$\rightarrow$ н лізі т оцінці функціонув ння соціоекосистем;

- метриз ції екологічних ст нів л ндш фтних систем;

- p ціон льному використ нні т охороні земельних ресурсів.

оцент ойнов . . фер н укових інтересів: нтропогенний вплив і тр нсформ ція л ндш фтних систем, зб л нсов ний розвиток територій, екологічний менеджмент, $\mathrm{p}$ ціон льне природокористув ння т охорон природи.

уковий доробок: 65 публік цій, з яких дві моногр фії (у спів вторстві), чотири н вч льних посібники в тому числі один з грифом , один словник (у спів вторстві), 43 ст тті, з яких 10 опубліков но у існику. ідготув л спір нтку . . икитч к, к ндид тськ дисерт ція якої рекомендов н до з хисту. перспективі м є н мір зосередитися н :

$\rightarrow$ поглибленні теоретико-методологічних основ дослідження нтропічного н в нт ження н л ндш фтні системи;

$\rightarrow$ нтропічній тр нсформ ції л ндш фтів з хідного регіону кр їни;

$\rightarrow$ роботі з спір нт ми.

оцент ерх ч . . фер н укових інтересів: соціоекологічні дослідження; демогр фічні процеси; екологія людини; охорон водних ресурсів; екологічні проблеми комунік ційних систем.

уковий доробок: ерх ч . . є втором і спів втором пон д 50 н укових пр ць, 3 яких, дві-н вч льні посібники, 45 ст тей (в тому числі шість-у існику).

под льшій роботі пл нує зосередитися н :

$\rightarrow$ підготовці н вч льного посібник “ кологія людини”;

$\rightarrow$ дослідженні демогр фічної т екологічної ситу ції в з хідному регіоні кр їни;

$\rightarrow$ вивченні водно-ресурсного потенці лу з хідного регіону кр їни.

оцент ожко . . фер н укових інтересів: екологічний туризм; орг ніз ція рекре ційної діяльності н гірських територіях; поводження з відход ми; еколого-економічні спекти розвитку територій; еколого-геогр фічні проблеми л ндш фтів гірського м сиву орногори.

уковий доробок: є втором і спів втором пон д 50 н укових $n p$ ць, 3 яких дві моногр фії, чотири н вч льні посібники, 45 ст тей (в тому числі $\boldsymbol{n}$ 'smb - у існику). ід його керівництвом 3 хищен одн к ндид тськ дисерт ція ( езручко . ., 2010). перспективі пл нує досліджув ти:

$\rightarrow$ проблеми регіон льного розвитку екологічного туризму;

- н прямки екологіз ції виробництв ;

- зосередитися н роботі з спір нт ми. оцент енчин . . фер н укових інтересів: природно-з повідн спр в ; екологічний туризм; кр єзн вство; екологічний удит.

уковий доробок: є втором і спів втором 68 н укових пр ць, з яких чотири моногр фії, чотири н вч льних посібники, в тому числі один - 3 грифом , 36 ст тей (в 
тому числі $\boldsymbol{m p} \boldsymbol{u}-\mathrm{y}$ існику). т ті присвячені впливу біотичних т біотичних чинників середовищ н поширення ркто- льпійських рослин, проблем м ст лого функціонув ння н ціон льних п рків. перспективі пл нує зосередити ув гун :

$\rightarrow$ дослідженні суч сного ст ну т проблем х збереження фіторізном ніття у меж $\mathrm{x}$ територій т об'єктів природно-з повідного фонду,

$\rightarrow$ розробці з ходів щодо формув ння екологічної мережі т тр нскордонних природоохоронних територій;

$\rightarrow$ роботі з спір нт ми.

оцент иротюк . . фер н укових інтересів: дослідження поновлюв них джерел енергії; проблеми з бруднення тмосфери; менеджмент природних ресурсів. уковий доробок: $є$ втором і спів втором пон д 60 н укових $n p$ ць, з яких один н вч льний посібник з грифом кр їни, 39 ст тей, з них дев'ятв - у існику.

перспективі пл нує розробляти:

$\rightarrow$ пр ктичні спекти оцінюв ння потенці лу поновлюв них джерел енергії;

$\rightarrow$ вплив м лих н природні територі льні комплекси.

оцент тойко .. фер н укових інтересів: дослідження проблем історичного л ндш фтозн вств ; історії геогр фії т к ртогр фії; л ндш фтної екології; геогр фічного прогнозув ння.

уковий доробок: тойко ..є втором і спів втором близько 190 н укових $n p$ иь, 3 яких трьох моногр фій (в тому числі у двох з них - втор передмови т упорядник) т двох н вч льних посібників, 141 ст ті (у тім числі трьох - у існику).

л нує зосередитися н :

$\rightarrow$ з вершенні докторської дисерт ції;

$\rightarrow$ підготовці моногр фії про відомого укр їнського геогр ф ригорія еличк ;

$\rightarrow$ опр цюв нні проблем історичної геогр фії, геогр фічного прогнозув ння, концепцій природокористув ння.

систент ілоус . . фер н укових інтересів: екологія територій гірничого виробництв ; екологічний менеджмент; норм тивне з безпечення природоохоронної діяльності.

уковий доробок: ілоус . . є втором і спів втором 44 н укових $n p$ ць, з яких одн моногр фія, 28 ст тей (в тім числі $\boldsymbol{n}$ 'яmb - у існику). йближчим ч сом пл нує 3 вершити к ндид тську дисерт цію.

систент, к.г.н. $\quad$ л жко . . фер н укових інтересів: проблеми використ ння й охорони перезволожених л ндш фтних систем; оцінк ст ну т охорон боліт і м лих річок.

уковий доробок: $є$ втором і спів втором 20 н укових $n p$ иь, 3 яких одн моногр фія (у спів вторстві), девя'ти ст тей (у тім числі три - у існику). ем тик н укових пр ць пов'яз н з теоретичними спект ми вивчення перезволожених л ндш фтних систем, їх кл сифік цією т моніторингом.

л нує зосередити ув гу н :

$\rightarrow$ підготовці моногр фії про перезволожені л ндш фтні системи ьвівської обл сті;

$\rightarrow$ вивченні суч сного ст ну боліт т з болочених територій;

$\rightarrow$ м лих річок т озер ьвівської обл сті.

систент, к.г.н. еліш . . фер н укових інтересів: проблеми використ ння т охорони лісових ресурсів, кр єзн вство, туризм. 


\section{ПІДРУЧНИКИ ТА НАВЧАЛЬНІ ПОСІБНИКИ}

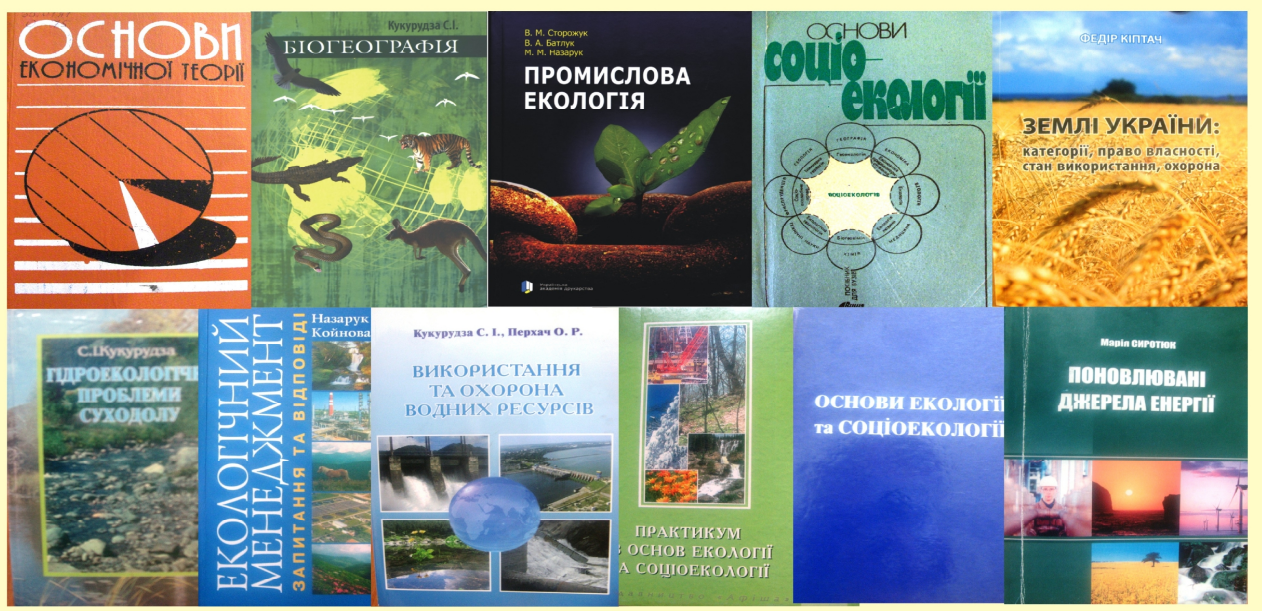

МОНОГРАФІЇ ТА ЗБІРНИКИ НАУКОВИХ ПРАЦЬ

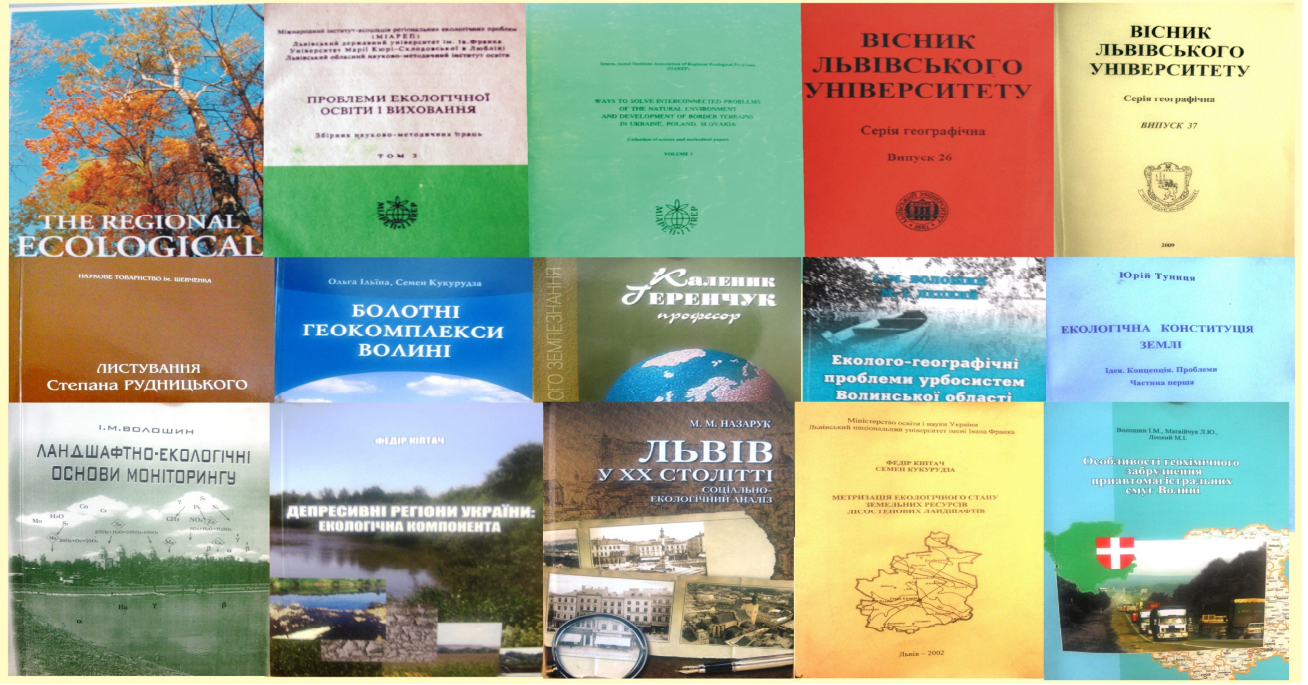

уков продукція викл д чів к федри р ціон льного використ ння природних ресурсів і охорони природи.

еліш . . опублікув в 10 пр ць, з них чотири - у існику. сі пр ці стосуються проблеми використ ння гірських лісів кр їнських рп т.

перспективі пл нує зосередитися н :

$\rightarrow$ дослідженні рен тур ліз ції тр нсформов них лісів;

- розробці схем екологічної мережі, кр єзн встві.

m. $л$ бор нт, cn. удоб . . фер н укових інтересів: менеджмент регіон льних л ндш фтних п рків; з стосув ння -технології в з повідній спр ві; оптиміз ція природокористув ння н природоохоронних територіях. 
уковий доробок: удоб . . . є втором 10 н укових пр ць, з яких $n$ 'яти ст тей, в тому числі двох - у існику.

л нує зосередитися н $з$ вершенні к ндид тської дисерт ції.

m. $л$ бор нт, пошукув ч рук . . фер н укових інтересів: етноекологія, збереження етнокультурної сп дщини н природоохоронних територіях, екологічний туризм. уковий доробок: $є$ втором 11 н укових пр ць (у тім числі одн ст ття опубліков н у існику).

л нує зосередитися н $з$ вершенні к ндид тської дисерт ції.

нженер, пошукув ч ик йло . . фер н укових інтересів: вплив втом гістр лей н екологічний ст н прим гістр льних екосистем.

уковий доробок: ик йло . . опублікув л одну ст ттю у існику.

л нує зосередитися н підготовці к ндид тської дисерт ції.

тосовно поб ж ння ред кційній колегії існик, пропонуємо повернутися до рубрик ції тем тики ст тей, як це було р ніше, не друкув ти їх в лф вітному порядку вторів. е д сть змогу з цік вленим чит ч м сконцентрув ти ув гу н н й кту льніших публік ціях. руге поб ж ння стосується форм ту існик , який з незрозумілих причин в ост нньому числі змінено. я пропозиція стосується не стільки ред кційної колегії існик, як ид вничого центру ьвівського н ціон льного університету імені в н $\mathrm{p}$ HK .

икл д чі, співробітники т спір нти к федри р ціон льного використ ння природних ресурсів і охорони природи впродовж трив лого ч су плідно співпр цюють 3 ісником ьвівського університету. ерія геогр фічн . Г лом, включно з спір нт ми к федри, вони опублікув ли н його сторінк х м йже 150 ст тей. ри числ існик (17, $26,37)$ - підготовлені з безпосередньої уч сті співробітників к федри.

еред викл д чів к федри першими втор ми існик ст ли укурудз .. (випуск 10, 1976 р.), тойко .. (випуск 12, 1980), иротюк . . (випуск 14, 1984).

йбільшу кількість пр ць у існику опублікув ли професори олошин . . - 19 , укурудз ..-18, з рук . . -18 , іпт ч .. .-11, ойнов . .- 10 .

ост нньому числі існик (№ 39, 2011 р.) перші ст тті опублікув ли молоді н уковці к федри - удоб . . ( спір нт) і ик йло ...(пошукув ч, у спів вторстві).

ж ємо їм, як і всім іншим втор м існик, гідно предст вляти геогр фічну н уку в цьому вторитетному ф ховому вид нні ьвівського н ціон льного університету імені в $\mathrm{H}$ p $\mathrm{HK}$. 


\title{
RETROSPECTIVE ANALYSIS AND PROSPECTS OF THE STUDIES AT THE DEPARTMENT OF RATIONAL USE OF NATURAL RESOURCES AND NATURE CONSERVATION
}

\section{S. Kukurudza}

Ivan Franko National University of Lviv,

. Doroshenko St., 41, UA - 79000 Lviv, Ukraine

The Department of Rational Use of Natural Resources and Nature Conservation at Ivan Franko National University of Lviv was founded in 1988. Since that time the professors, the staff and the doctorate students have cooperated fruitfully with the scientific publisher - Visnyk Lvivskoho Universytetu. Seriya Geografichna. They have published here almost 150 papers. This paper analyzes scientific activities of the department's staff, especially those reflected in different issues of the Visnyk, as well as the prospects of the research, as perceived by the department's staff.

Key words: department, Visnyk, scientific interests, scientific achievements, research prospects.

\section{- укурудз}

\author{
ьвовский н иион льный университет имени в н \\ ул. . орошенко, 41, г. ьвов, 79000, кр ин
}

федр р цион льного использов ния природных ресурсов и охр ны природы ьвовского н цион льного университет имени в н р нко обр зов н в 1988 году. этого времени препод в тели, сотрудники и спир нты к федры плодотворно сотруднич ют с н учным изд нием естником ьвовского университет . ерия геогр фическ я. его стр ниц х н печ т но почти 150 р бот. ст тье про н лизиров н н учный з дел сотрудников к федры, в ч стности, т его сост вн я, котор я отобр жен в р зных выпуск х естник, под ётся виденье сотрудник ми к федры перспективных н пр влений н учных исследов ний.

лючевые слов : к федр, естник, н учные интересы, н учные достижения, перспективные н пр вления исследов ний. 